\title{
Property Rights Implications for the Brazilian Forest Code ${ }^{1}$
}

\author{
Bernardo Mueller²
}

\begin{abstract}
The Brazilian Forest Code restricts landowners' uses of the land. Changes in property rights are therefore the core element of the program. In this paper the new institutional literature on property rights is used to analyze the main difficulties involved in such a re-specification of rights. Four concepts from this literature are described and applied to better understand the issues that have hindered the program in the past and that affect the current version of the program initiated in 2012: (i) property rights as a 'bundle of rights', (ii) evolution of property rights, (iii) path dependence; and Ostrom's 8 design principles. The paper argues that the key issue for the Forest Code is the level of uncertainty of the gap between the de jure and de facto specification of property rights.
\end{abstract}

Key-words: property rights, Forest Code, Brazil, land policy.

Resumo: A essência do Código Florestal brasileiro é uma alteração nos direitos de propriedade que restringem os usos que os proprietários podem fazer da terra. Neste trabalho, a literatura da nova economia das instituições relacionada à direitos de propriedade é usada para analisar as dificuldades e problemas envolvidos em uma reespecificação de direitos de propriedade desta natureza. Quatro conceitos desta literatura são descritos e aplicados para entender os problemas que o Código Florestal tem encontrado e que certamente irão persistir na nova versão do programa iniciada em 2012: (i) direitos de propriedade como um feixe de direitos (bundle of rights), (ii) evolução de direitos de propriedade, (iii) dependência da trajetória (path dependence) e (iv) 8 princípios para governança de Elinor Ostrom. O trabalho argumenta que a principal questão para o funcionamento do Código Florestal é o nível de incerteza relacionado ao hiato entre as especificações de jure e de facto dos direitos de propriedade.

Palavras-chaves: direitos de propriedade, Código Florestal, Brasil, politica de terras.

JEL Classification: Q15, Q23, D23, Q58.

DOI: http://dx.doi.org/10.1590/1234-56781806-94790560209

1. Data de submissão: 29 de maio de 2017. Data de aceite: 22 de outubro de 2017.

2. Universidade de Brasília. Brasília, DF, Brasil. E-mail: bmueller@unb.br 


\section{Introduction}

In 2012 Brazil revised its Forest Code legislation which regulates private land use and management by mandating landowners to set aside in native vegetation and leave unused an area equal to $20 \%$ of total property area (80\% in the Amazon). The Forest Code was initially established in 1934 to promote fuel conservation, was reformulated in 1965 to promote the economic development of forest based industry, but since the mid 1990's has become as an environmental law (HIRAKURI, 2003). Until recently government had failed to effectively enforce the Forest Code, as neither the political consensus nor the administrative capabilities seemed to be in place. The recent revision of the legislation, however, indicates that both of these circumstances are changing and that a more realistic effort at actually implementing the Forest Code will be made this time. If this does in fact prove to be the case, this might be Brazil's grand policy experiment in the area of property rights. It is a grand experiment because the size of the country makes the area and population involved reach continental proportions. Other Brazilian policies that involved intervening directly with individuals' property rights, such as the land reform program or the occupation of the Amazon, pale in comparison in terms of magnitude and reach, as they did not apply to all or even most properties in the country. And as those policy experiences have shown, interventions that require altering property rights tend not to be as straightforward as they can initially seem, often eliciting unexpected behavior and yielding unintended consequences. These difficulties are compounded by the fact that the Forest Code legislation is one of the most draconian land laws in the world, requiring landowners to set aside significant fractions of their properties, with non-trivial impacts in terms of foregone production possibilities and reduced rental streams that must be fully absorbed by the owners without compensation. On the other hand, it is precisely because of its massive magnitude, depth and coverage that the Forest Code has the potential to really have a profound positive environmental impact (SOARES-FILHO et al., 2014; CHIVARI and LOPES, 2015). The purpose of this paper is to assess how the nature of property rights to land in Brazil will affect the implementation of the Forest Code and the realization of the potential positive environmental impacts. This involves analyzing the historical evolution of property rights in Brazil and an institutional analysis of how property rights affect the incentives and behavior.

In the past two decades, there has come to be a consensus in the academic literature about the fundamental role played by institutions - as rule of the game - and property rights in determining economic decisions and outcomes (NORTH et al., 2009; ACEMOGLU and ROBINSON, 2012). Secure and well defined property rights are widely recognized as crucial inputs for investment, development of markets, better use of resources and economic growth. But whereas this recognition is widespread, the notion of property rights that is used is often highly simplified. Property rights are often seen as a one-dimensional concept that can be either 'secure' or 'insecure', or possibly put into an index that varies from zero to one to be used in cross-country regressions. Whereas such an approach 
can be useful for the type of questions addressed in cross-country comparisons, when it comes to understanding how individuals' and groups' choices and behavior are affected when using a resource such as land, a more rigorous understanding of the property rights is necessary. Property rights are not a relation between an individual and a thing, such as land, but rather a relation between different individuals related to the use of a thing. This means that a property right specifies a list of abilities and restrictions that apply to both the owner and to other members of society (BARZEL, 1997). Furthermore, property rights are not a single blanket right that covers every aspect of the property, rather it is composed of many different dimensions each or which refers to different attributes. For example, a property right to a piece of land might give the holder the right to sell, lease, subdivide, and fence the property, while giving a neighbor the right to cross, to pursue hunted animals and to be free from noxious odors emanating from the property, while society retains the rights to subsoil minerals, to tax and to regulate the property. The Forest Code is essentially a re-specification of property rights that limits landowners' right to clear all of their land and confers to society the right to the environmental benefits of having native vegetation on each piece of land. To further complicate matters, it is almost never possible or economically rational to fully enforce the formal property rights specified by laws and regulation so that the de facto property rights that provide the incentives for land use choices are generally disjoint from the de jure property rights on paper. This wedge between de jure and de facto may not be very consequential if there is wide agreement and certainty that what truly applies are the de facto rules that everybody has actually been abiding by. But when there is uncertainty whether the de facto rights will always prevail or whether the de jure rights might be invoked by other claimants or by the government, then there can arise incentives for unproductive, opportunistic and defensive behavior that can dissipate much of the land's rental streams through suboptimal land use and suboptimal investment, as well as through conflict, violence and environmental degradation. This paper argues that one of the major challenges for the Forest Code has been and will continue to be the insecurity of property rights that emerges from the uncertainty between de jure and de facto rights.
Because property rights involve multiple dimensions and are difficult to enforce, it follows that both academic analysis and actual policymaking are often trickier than one might initially expect. For many years, experts had presumed that the only way to avoid the Tragedy of the Commons, where resources are over-used due to lack of clear ownership, was to resort to strong, clear property rights, either in the form of private property or state ownership (HARDIN, 1968). The presumption was that in the absence of either of these solutions, prisoner dilemmas and problems of collective action would inevitably lead to the tragedy of the commons. And yet, as noted by Elinor Ostrom in her research on common property management of natural resources, small groups and communities across the world and throughout history have managed to establish governance mechanisms to use resources such as land, water, forests, pastures etc. in sustainable ways (OSTROM, 1990). Whereas this insight might seem obvious once it has been stated - and rewarded with a Nobel Prize in 2009 - it is still often ignored in the literature and in policymaking.

Another example of the elusive nature of property rights is the influential argument made by Hernando de Soto in "The Mystery of Capital" (SOTO, 2003) that that if the poor were granted title to the houses and land they possessed, they would access credit and enter the formal economy. This would allow the poor to leverage property into wealth and would allow poor countries to access the same kind of gains from capitalism that have been experienced by developed countries. This thesis became highly popular among politicians and policymakers in different countries and led to several programs to better define and secure property rights so as to unlock this potential. Without getting into the merit of such programs, it is noteworthy that even in de Soto's prototypical case of urban slums in Lima, Peru, although the policy to strengthen property rights was found to have led to greater residential investment, this did not take place as expected through credit obtained by using the newly-titled property as collateral. Banks continued to withhold credit to the poor because they realized the political difficulty of foreclosing despite formal titles (once again an uncertainty between de jure and de facto rights). Instead, the improved investment was found to have been unexpectedly driven by the greater employment possibilities that arose once secure title 
obviated the need for some family members to have to be constantly at the house to defend the property (FIELD, 2005).

Several other examples of the difficulty of reforming property rights could be mentioned, such as the mass collectivization of farmland in the Soviet Union and China; two other historical grand experiments with property rights. The point is that although the basic intuition that clear and secure property rights are crucial for good economic performance is correct, the way in which property rights affect incentives and behavior is complex and subtle, so that policy based on property rights has to carefully consider the specificities of the context and the nuances of how property rights work. This paper does exactly this for the case of property rights to land in Brazil and its implications for the Forest Code. The next section provides four concepts or insights from the economic theory of property rights that make it easier to understand the subtleties involved in specific cases. These analytical tools will then be used in the subsequent sections which turn to the Brazilian case. Section 3 then takes stock of the research on the impact of property rights to land in Brazil in order to establish what outcomes in terms of economic performance have been realized and how they were crucially impacted by property rights. Because many of these experiences have much in common with what is being pursued by the Forest Code, the cases that are analyzed hold many lessons and insights for this grand policy experiment. In particular, Section 4 details the process of land reform which has been continuously pursued in Brazil through many different programs since at least the mid-20 $0^{\text {th }}$ century. Many of the shortcoming of these land reform programs were related to property rights issues that can potentially impinge of the Forest Code program. Section 6 concludes on a positive note by pointing out some ways in which the Forest Code might be better positioned to succeed than any of the previous programs.

\section{Four concepts to understand property rights}

Given the multidimensional and dynamic nature of property rights it is useful to have some analytical tools in order to understand how they arise and how they impact economic agent's choices and behavior. In this section, four concepts from the property rights literature are briefly presented, providing insights that will be used in subsequent sections to analyze property rights in Brazil.

\subsection{Property as a bundle of rights}

Legal scholars often use the metaphor of a 'bundle of sticks' to think about property rights, where each of the sticks in the bundle represents a specific attribute of the object. ${ }^{3}$ These attributes refer to the many different uses and actions that can be taken with the object. Because property is a relation among different agents with respect to an 'object', each of these attributes is an ability or a restriction on the owner or on the rest of society. Thus, the bundle of rights is a form of listing these abilities and restrictions for each of the potential uses of the object. A bundle of rights for a piece of land, for example, might allow the holder to plant, subdivide, fence, leave fallow etc., and grant society the right to tax, take in eminent domain, or require the presence of a legal reserve in native vegetation.

Figure 1 shows an example of a bundle of rights related to a piece of land. The bundle specifies which rights are held by the 'owner', and which are held by the state and by third parties. The usefulness of stating property rights in this way is that it makes explicit the incentives and constraints faced by the property holder given those specific property rights. The basic oversimplified notion that 'good' property rights are important for good economic performance becomes much more detailed and powerful when it is stated in terms of a bundle of rights that specifies each of the rights and shows each of the holders of those rights. The metaphor also makes it clear that the bundle can be assembled in many different ways by separating, combining, trading, and contracting the sticks in the bundle. Each combination of rights in the form of a bundle provides different incentives and constraints and thus lead to different outcomes and performance. A policy recommendation for a program such as the Forest Code involves finding a bundle of rights that simultaneously achieves the

3. For a series of papers debating appropriateness of the bundle of rights metaphor see (KLEIN and ROBINSON, 2011). 
Figure 1. Property as a bundle of rights

Owner's bundle of rights

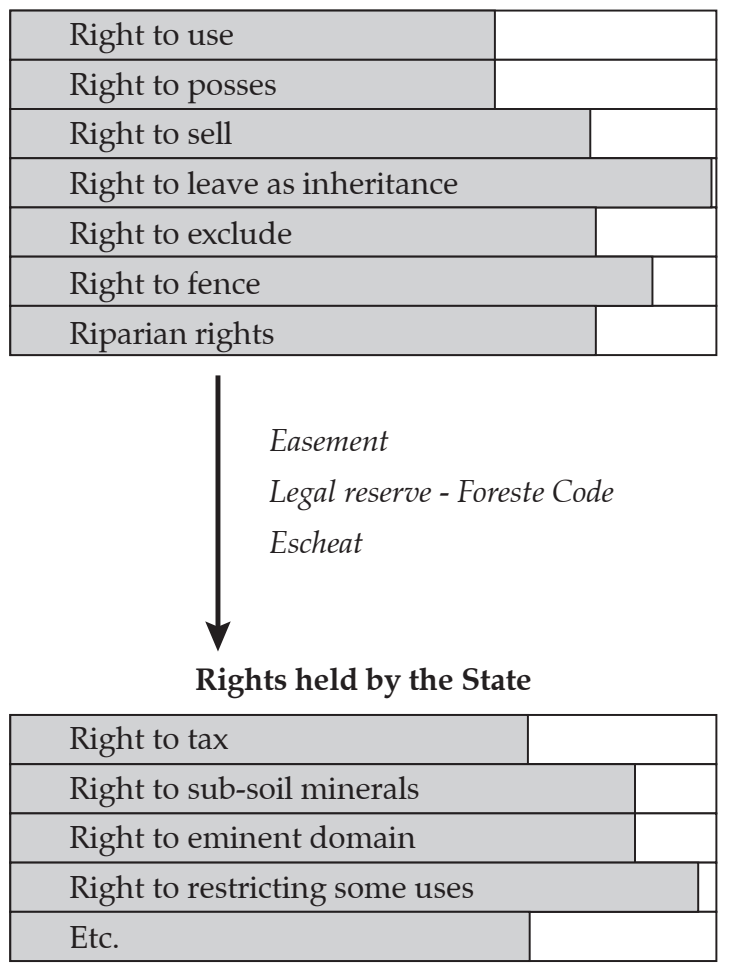

Source: Created by the author.

sought after environmental protection together with productive use of the land, while providing incentives for compliance.

Figure 1 also shows that each of the sticks in the bundle are shorter than they could be. This reflects the fact that rights are never fully enforced, so that some of the rights are left in the public domain where they can be captured by others. Even if a State is present to protect property rights, the extent of the enforcement is always incomplete, as monitoring and policing is costly. Because of this, individuals also expend resources to enforce their property rights in addition to what is done by the state. Instead of relying completely on the state, for example, most people still lock their doors and even install security systems. But even here enforcement is never complete. Because enforcement is costly, individuals will only choose to expend resources securing their rights up to the point where the benefits from doing so are worth the cost. One could, for example, hire security guards to stand by your car when you park it on the street. But the
Rights held by third parties

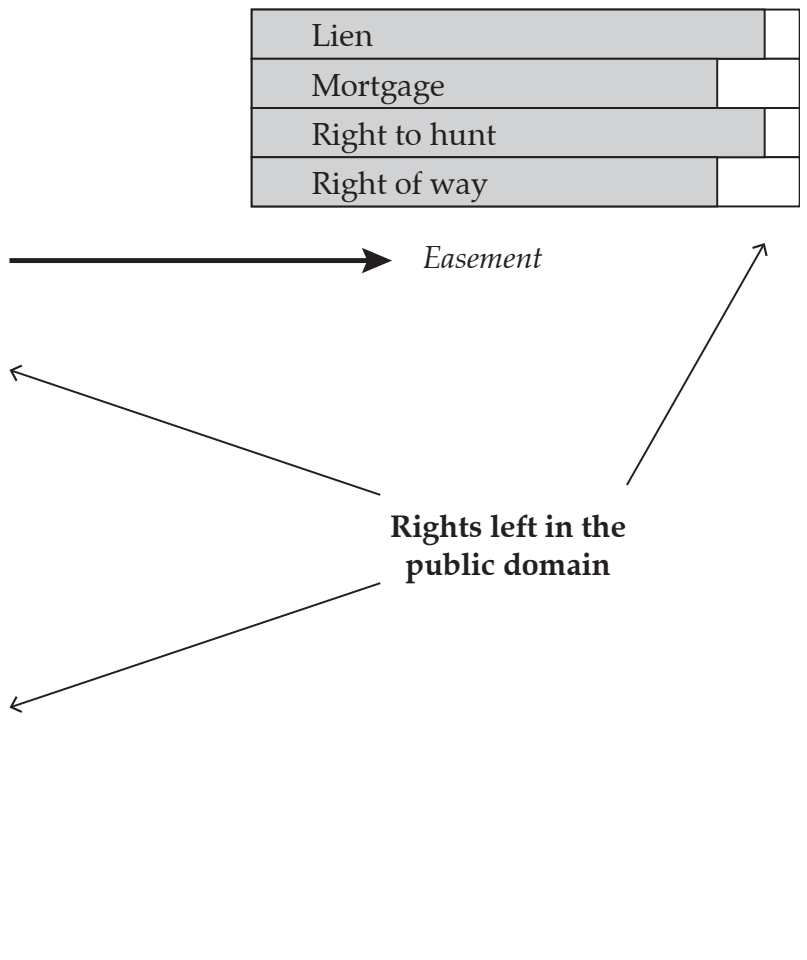

added protection would probably not compensate the expected reduction in probability of the car being stolen, so it is rational to leave part of the right to the car in the public domain.

Because of the transaction costs of specifying and enforcing property rights it turns out that the bundle of rights that effectively constrains and incentivizes the players will often by considerably different than the formal property rights in the laws and regulations. That is, the de facto property rights can diverge significantly from the de jure property rights. This does not mean that the de jure rights are irrelevant or innocuous for they represent the expectation of how society, or those making the laws, envisioned the property rights as working. This means that even if the de jure property rights are not currently fully constraining, they could come to life in the future, as it is often easier start enforcing latent laws that have already been passed than it is to legislate completely new laws.

The key issue is the expectations of the players related to what bundle of rights they hold now and in 
the future. To illustrate, start with a situation in which there is no uncertainty about the enforcement of the rights now or in the future, so that de jure and de facto rights are the same. Suppose additionally that the bundle of rights is constructed so as to induce 'good' outcomes for both the owner and society. If we now introduce some transaction costs so that there is a wedge between de jure and de facto rights, there might be some rent dissipation and inefficiencies relative to the prior situation. Some of the rights are now partially in the public domain where they can be captured by others and the holder might incur unproductive expenditures to protect those rights. But as long as there is reasonable certainty about what the rights are, a second-best situation will prevail where the de facto rights effectively determine incentives and constraints. In the Brazilian Forest Code, for example, there has long been a great divergence between de jure and de facto rights, where the law required the maintenance of a Forest Reserve in each property but because of lack of enforcement it was tacitly understood that one could fail to abide by this stipulation with little chance of triggering a sanction. But if something changes that cast doubt on whether it is the de jure or the de facto that will heretofore prevail, the uncertainty will upset the previous second-best incentives and might lead to greater distortions and rent dissipation. With the revision of the Forest Code and the revised commitment of the government to this time actually implement the program, there is now uncertainty as to where landowner's property rights actually stand. The conditions for pushing forward with the program are stronger than they have ever been, with considerable support from society, social movements and the international community having generated considerable political will to move ahead. In addition, technological advances have made the logistical task of surveying, registering and monitoring properties and compliance easier and more efficient. And yet, even with these favorable forces the implementation of the program remains a formidable task. Different individuals will have different assessments of whether this time the program will effectively take off. This uncertainty makes it unclear whether the de facto or the de jure rights are the ones which should be acted upon, thus leading to unsecure property rights which impact individual's behavior and economic performance. Sending a signal that de new de facto rights are the same as the de jure rights is crucial for the program's success. But this is difficult to do because a credible signal requires actually implementing the program according to plan, while implementing the program depends on a large measure on the agent's perception that the property rights have truly converged. The best way to achieve this credibility is to go ahead with the program as planned and by demonstration achieve a gradual deepening of beliefs that the rules have effectively changed.

\subsection{The evolution of property rights}

The discussion about property as a bundle of rights makes it clear that property rights are a dynamic concept, that is, they change over time. It is thus important to understand what determines that process of change. How do property rights first emerge and how do they evolve? A frontier can be thought of as a place or a situation where there is no scarcity of a given good and thus where property rights are either nonexistent or irrelevant if they exist. Because the good is abundant relative to demand, there is no competition for the good and the lack of property rights is innocuous, as it will not lead to conflict or rent dissipation. But if at some point a shock takes place that increases the demand for the resource, competition to appropriate it, conflict, violence and other forms of rent dissipation will arise. This increase in demand can come about due to a demographic, technological, preference, climatic, or other types of shocks, which brings in new potential appropriators, introducing scarcity in the place of abundance. Whereas before the change there was no need for formal property rights and competing claims could be mediated through norms, now there are many heterogeneous competitors and norms are no longer sufficient.

An influential thesis by Harold Demsetz suggests that at this point there arises a 'demand' for property right (DEMSETZ, 1967). The losses and inefficiencies inherent in a situation where property rights, or lack thereof, induce unproductive competition and rent dissipation would prompt the holders of the assets to seek to devise new property right that internalize externalities and eliminate the inefficiencies. His classic example are the Quebec Indians who prior to contact with Europeans appropriated beavers through an open access rule, first-come-first-serve. Given the size of the 
population of beavers relative to the demand from the Indians, this was an 'efficient' rule which assured the productive and sustainable use of the resource. But once the demographic shock represented by the arrival of Europeans had opened the large-scale fur trade to the Indians, the former property right rule of open access was no longer 'efficient', as the increased competition for fur pushed the population of beavers towards its carrying capacity. According to Demsetz's account the associated losses pushed the Indians to change the property rights to beavers to a system of private property, where different groups of beavers where assigned to specific individuals who could exclude others. By making each individual the residual claimant for his/her own set of animals there were incentives to internalize the externalities - a beaver not killed today would still be yours tomorrow - and 'efficiency' was once again achieved. ${ }^{4}$

Demsetz's theory of property rights evolution thus saw rights evolving optimally whenever the relative prices changed and the current rule no longer worked properly to provide incentives for 'efficient' resource use. Although very influential, this view was criticized for accounting only for the demand for property rights and simply assuming that a supply would automatically emerge. ${ }^{5}$ In most situation the supply of property rights is filtered through the existing political system and there is no guarantee that the new chosen property right rules will be those which are best for society. If the efficient rule under the new conditions is not in the interest of those who hold power, it will probably not be put in place, even if this implies social losses. Political transaction costs impede contracting away the inefficiencies so that property rights that promote inefficient behavior and rent dissipation may arise and persist. The prevalence of situations with these characteristics throughout history and across countries indicates that such outcomes are not at all unlikely.

The upshot from this discussion is that when circumstances change there are forces for property rights to change. Whenever the current bundle of rights

4. For a more detailed analysis of the evolution of property rights see (ALSTON et al., 2012). For a Darwinian theory of property rights evolution see (ALSTON and MUELLER, 2015).

5. See (EGGERTSSON, 1990) for a critique of Demsetz's theory. is not inducing the best use of assets and resources there is space to try to improve incentives by adapting the property rights. But even if the design of a superior new bundle of rights is obvious to all, it will not necessarily be achieved, so that inefficient configurations can persist for long periods of time. Negotiation among stakeholders can help to move the rights towards more efficient designs, but political transaction costs can make it difficult to make the credible commitments that are typically required in this kind of intertemporal political transaction. The success of the Forest Code depends on this kind of transaction. There are clear gains to changing the current uncertain property right given the strong presence of externalities in terms of deforestation, carbon and biodiversity, as well as the lack of security for production and investment. The negotiation for this change takes place in a status quo in which each side's willingness for exchange depends on their current endowment and the value today and hereafter of what they give up and what they receive. That is, the necessary political exchanges require consensually secure property rights. As suggested above, the best way of achieving this is to pursue the program in such a way to create through consistent action a gradual deepening of the belief in the new set of property rights.

\subsection{Property rights and path dependence}

Because property rights are difficult to change, even in the presence of clear gains to trade, it turns out that they are typically highly path dependent. Path dependence means that property rights tend to persist with the same design over long periods of time. It also means that the form taken by property rights are highly contingent to initial conditions when they first emerged. Both of these characteristics are illustrated by the comparison by Engerman and Sokoloff of the different colonization trajectories of countries that emerged from the discovery of the New World in the $15^{\text {th }}$ century (SOKOLOFF and ENGERMAN, 2000). They argue that where European colonizers encountered labor that could be coerced or imported (slavery) for the production of precious metals or large scale plantations, institution were put in place to enable that form of economic organization. These were extractive and coercive institutions that lead to high inequality of land and wealth, with power 
concentrated in a small elite. This configuration of institutions naturally led to policies (i.e. educational, immigration, access to land, franchise, access to credit, judicial, etc.) that perpetuated the concentration and exclusion over time, thus the path dependence. On the other hand, colonies where there was no possibility of using coerced labor, such as the US and Canada, led to more inclusive institutions that gave rise to a more equal society. Here too path dependence meant that inclusive institutions produced inclusive policies that perpetuated the nature of open access societies. Because inclusive institutions are more conducive to economic growth and development over the long term than extractive institutions, it turned out that the colonies that started out producing greater wealth and activity eventually became poorer than those that were initially more impoverished, in a 'reversal of fortune' (ACEMOGLU et al., 2005).

The point here is to stress that although property rights evolve and can be changed, which was the message of the previous sub-section, history nevertheless matters and what can be achieved in designing property rights is highly contingent on how the current set of property rights and distribution of power were reached. Since the Forest Code was revived in the mid-1990's it has been a highly controversial and disputed issue. In many ways, it is quite surprising that the Forest Code legislation has been so prominent in the country's policymaking agenda. Many people assumed that because landowners are well-organized and well-represented in Congress, they could dominate the political debate regarding this issue. But if they were the single dominant interest, the Code would have been abandoned long ago. The fact that it has been persistently kept in the policymaking agenda indicates that there are also strong interests in favor of an effective implementation of the Forest Code, including environmental interest groups and voters. The fact that the most disputed votes in the 2012 revision of the Code in Congress revolved around parametric details instead of the actual decision to pursue or not the policy, indicate that both sides are relatively well matched (ALSTON and MUELLER, 2007). The balance of power between the different interests is a crucial determinant on what form the Forest Code will actually take as it gets implemented. Path dependence in a country with one of the highest levels of landownership concentration has made the evolution of Forest Code legislation slow and uncertain. But changes in Brazilian society's beliefs and preferences show that though history matters, endowments are not fate.

\subsection{Design principles of robust property rights institutions}

The previous three points have argued that property rights are complex, multidimensional, possibly different from the de jure rules and are evolving but hard to change. What more practical lessons are there in property rights literature for the design and implementation of the Forest Code?

One of the most acclaimed approaches to understanding and designing property rights has been that of Elinor Ostrom who noted that small groups and communities throughout the world often defy the received wisdom that resources held in common property are inevitably fated to fall into the tragedy of the commons (OSTROM, 1990). Ostrom's 'Law' proposes that "a resource arrangement that works in practice can work in theory" (FENNELL, 2011). This insight started a large literature that collected numerous cases related to all sorts of assets and resources, showing that these groups are frequently able to self-organize governance structures, that is bundles of rights, which can lead to sustainable uses of the resources. From the lessons learnt from this large catalogue of cases of successful and failed common property resource use, Ostrom distilled eight design principles of property rights institutions (OSTROM, 1990, 2009). Design principles are not specific rules, but rather more abstract institutional regularities at a higher level of generality that are common to many instances of successful resource management. Although the Forest Code deals directly with private property and not common property resources, the environmental role of the Legal Reserves means that there is an important common property dimension, so these principles can still be helpful. Rather than listing the eight design principles, however, Table 1 shows eight questions that translate the original principles into a form that is more directly relevant for a policymaker considering a specific policy.

Let us briefly see how some of these principles apply to the Forest Code. The first design principle requires the boundaries of the resource to be clearly 
Table 1. Design principles for robust property rights institutions

\begin{tabular}{|c|l|}
\hline $\mathbf{1}$ & $\begin{array}{l}\text { How can we better define the boundaries of this resource and of the individuals who are authorized to use it so as to ensure } \\
\text { clarity in who is authorized to harvest and where harvesting is authorized? }\end{array}$ \\
\hline $\mathbf{2}$ & $\begin{array}{l}\text { How can we improve the relationship between the benefits received and the contributions to the necessary costs of } \\
\text { sustaining this system? }\end{array}$ \\
\hline $\mathbf{3}$ & How can we enhance the participation of those involved in making key decisions about this system? \\
\hline $\mathbf{4}$ & Who is monitoring this system, and do they face appropriate incentives given the challenge of monitoring? \\
\hline $\mathbf{5}$ & $\begin{array}{l}\text { What are the sanctions we are authorizing, and can they be adjusted so that someone who makes an error or a small rule } \\
\text { infraction is warned sufficiently so as to ensure longer-term compliance without having to impose unrealistic sanctions? }\end{array}$ \\
\hline $\mathbf{6}$ & What local and regional mechanisms exist to resolve conflicts arising over the use of a resource? \\
\hline $\mathbf{7}$ & $\begin{array}{l}\text { Are there functional and creative efforts by local appropriators to create effective stewardship mechanisms for local } \\
\text { resources that should be recognized? }\end{array}$ \\
\hline $\mathbf{8}$ & How do we create a multiple-layer, polycentric system that can be dynamic, adaptive, and effective over time? \\
\hline
\end{tabular}

Source: OSTROM (2009).

defined. For the Forest Code this refers not only to the boundary of the property itself, but also to the size and location of the legal reserve and other required protection areas, such as river banks and steep slopes. The lack of registries, cadasters and maps in Brazil has long been an obstacle to land-related policy, including earlier versions of the Forest Code. Yet new technologies have greatly improved capabilities in this area. This principle ratifies the importance of efforts to establish clear boundaries.

The second principle requires a proportionality equivalence between the benefits from the Forest Code and the costs imposed by the system. According to (OSTROM, 2009) this principle:

[...] relates to the likelihood that participants will feel that the rules they are using are equitable. If some people pay low costs but they get high benefits over time, this inequity is a matter of frustration for the participants and may lead to more and more participants refusing to abide by the rules because they are unfair. Thus, this design principle is directly related to the types of attitudes that are necessary to sustain a system over the long run. If some users get all the benefits and pay few of the costs, few of the others are willing to follow rules over time (OSTROM, 2009, p. 26)

In the case of the Forest Code this issue is a central part of the controversy. The legislation imposes all the costs of maintaining a legal reserve on the landowners. These are very significant costs, composed of the opportunity cost of land use and in many instances the cost of restoring the vegetation. The landowners feel that the de facto legislation never effectively required a legal reserve and that mandating this now amounts to a regulatory taking. On the other hand, environmentalists note that the de jure legislation has been in place for decades and argue that landowners have already benefited all this time from being able to evade these rules, so that it is fair to now require compliance. What the second principle suggests is that this divergence in perspective can be very damaging to the program's success and warrants efforts to achieve some measure of consensus. In part, the efforts being made to reduce the costs of compliance, by for example allowing trading of forest reserve obligations from higher to lower opportunity cost land, serves the purpose of reducing the divergent incidence of costs and benefits.

These and other recommendations from the property rights literature that focus on institutions, power and context, can help design polices with greater prospects of achieving their goals.

\section{Impacts of property rights on social and economic performance in Brazil}

\subsection{Property rights and performance in Brazil}

A cursory look at the use of land in Brazil reveals signs of rampant rent dissipation in the form of conflict, violence, missing markets, suboptimal use, unsustainability, deforestation, missed opportunities 
etc. This section examines which pathologies related to land use in Brazil have been linked to property rights and how they affect the implementation of the Forest Code.

The historical evolution to property rights to land in Brazil was such that by $20^{\text {th }}$ century the norm was an extremely high concentration of landownership. The implication of this was that both in de jure and in de facto terms the rules for the allocation and use of land were fairly close, as both the laws and the physical reality privileged the landed elite. This state of affairs enabled a steady expansion of production and of the agricultural frontier after the Second World War, though at low levels of technology and productivity (MUELLER and MUELLER, 2014). However, gradually overtime there emerged in Brazilian society the belief that such extreme concentration of land and wealth was not desirable from an economic or a social justice perspective, and over the second half of the $20^{\text {th }}$ century there were several punctuated and intermittent attempts to institute policies to counter this state of affairs. Many of these attempts got written into laws and even in constitutions. Most were of limited or no effect as they often implied redistribution from the powerful elites to poorly represented groups in society, so they became dead letters. Yet starting in 1985, with re-democratization after two decades of military rule, the sentiment towards correcting the excessive concentration of land and wealth became a central belief in Brazilian society and not only induced more legislation imbued with this purpose, but also lead to greater success in having that legislation at least partially enforced. ${ }^{6}$ The 1988 Constitution was dominated by this sentiment and codified the belief in social inclusion. In many ways, the original document went too far in this other direction, contributing to the hyperinflation that followed, but over time many of the excesses of that document were revised and it has been an important instrument in the unprecedented fall in equality in Brazil from 1995 to the present (ALSTON et al., 2016).

This social change is important because it is the fundamental cause of what this paper has identified as the central problem of property right to land in Brazil: the divergence between de jure and de facto rights. In

6. For a detailed analysis of this period of Brazilian history and the emergence of a belief in social inclusion, see Alston et al. (2016). a first stage, as de jure rights started to incorporate rules that were contrary to the interest of the owners of land, the rules were simply ignored and the de facto reality prevailed. But as the belief in social inclusion became stronger, there was increasing pressure for the de jure rules to come into being and start to be implemented and enforced. Because the de facto rules have strong a constituency, a tension was created that led to increased uncertainty as to which was the actual status quo that now governed the allocation and use of land. This uncertainty resulted in rent dissipation and inefficiencies in the use and allocation of land. This section describes which impacts have been most pervasive in Brazil.

The clearest instance of this dynamic tension between de jure and de facto property rights to land described above can be seen in the institution of the notion of 'the social function of property' which appeared for the first time in the Land Statute of 1964 and which remains today as the overarching set of principles that any land-related rule must follow. As expressed in Article 2 (and later reiterated in the 1988 Constitution) the notion of the social function of land is as follows:

Article 2 The opportunity of access to ownership of land is secured to all, conditioned on its social function, as per this Law.

$\S 1^{\mathrm{o}}$ The property of land fulfills its social function when it simultaneously:

a) promotes the welfare of the owners and the workers who toil in it, as well as their families; b) maintains satisfactory levels of productivity; c) assures the conservation of natural resources;

d) observes the laws governing fair working relationships between those who own and those who cultivate it.

This paper has identified five major pathologies related to land use and allocation in Brazil that are linked to the fact that the wedge between de jure and de facto property rights has become more severe as the demand for social inclusion has clashed with the prevailing distribution of wealth and power. Most of these pathologies can be described in terms of the requirement that land fulfill its social function as stated in the Land Statute and the Constitution. This does not mean that it is the legislation itself that is having this 
effect. Rather, the Constitution codifies the dominant belief in social inclusion and equality that has pervaded Brazilian society in the past decades. It is the belief that creates the wedge. By awakening old de jure rules and enabling new potentially effective property rights, the social function of land was simply one of the means through which the belief has been expressed.

\subsection{Conflicts and violence}

Perhaps the most direct and obvious consequence of uncertain property rights are land conflicts and violence. Every process of frontier evolution in Brazil has been accompanied by conflict and violence, from the coffee frontier in the $19^{\text {th }}$ century described in Section 3.2, to the Amazon frontier starting in the 1960s. As relative prices change the previous property rights are no longer suitable for handling the increased competition and conflict ensues. Although conflicts have always been present, starting in the early 1990 's, the number of land related conflicts increased significantly in number and in prominence. Conflicts and violence are an obvious form of rent dissipation which indicate dysfunctional property rights, so why did this state of affairs become so prevalent?

This specific pathology is associated with the requirement in the 'social function of property' that land must 'maintain satisfactory levels of productivity.' This requirement has been the justification, since the Land Stature of 1964, for the choice of land reform through the expropriation of unproductive farms and transfer of the land to landless peasants that are expected to make it productive. Although the expropriation is compensated, in most cases it is punitive in the sense that it is imposed rather than negotiated, and can be below the original holder's valuation of the land. This style of land reform is in contrast with milder forms, such as distribution of public land or land reform through taxation. On the other extreme, it is less punitive than land reform through uncompensated expropriation.

Both the military government (1964-1984) and the new democratic regime put in place extensive land reform programs. The first because of the perception that the vast idle latifundia were an important obstacle to the project of creating a great industrialized power. The second because of social justice. Land reform was one of the major banners of the New Republic and a symbol of the social inclusion it prioritized. Yet neither of these regimes managed to actually implement the programs they created with much fanfare. Land reform under any circumstances is a difficult policy to implement. It is even harder in a large and undeveloped country such as Brazil at that time. In a country where wealth and power are so unevenly distributed, redistribution proved almost impossible. So during this period, up to the early 1990's, land reform was conspicuously present in the political debate and the policymaking scene, but had few practical results. In this period the disjuncture between de jure and de facto property rights was present, given this constant presence of land reform in daily life, but it was not too consequential given that the de facto reality clearly trumped the de jure aspirations. There were land conflicts at this time, but nothing like what is shown in Figure 2. But as the belief in social inclusion deepened in Brazilian society, the intent to make the de jure property rights prevail became increasingly stronger. The inclusion of the social function of property in the land reform section of the 1988 Constitution was by far the most controversial item of what was an intensely debated constitutional process (MUELLER, 1998).

These developments created the opportunity for well-organized peasants to increase their pressure for land reform. Led by the Landless Peasant Movement (MST - Movimento Sem Terra) the number of invasions of unproductive farms grew dramatically in the 1990's. The MST realized that if they would wait for the government to follow through with its announced land reform programs, nothing would be accomplished. So they devised the strategy of invading land that fit the requirements for being expropriable (unproductive and/or weak title) as a means to force the government to expedite their efforts. Land reform in this period was fully driven by MST pressure, that is, land reform happened where they invaded. The intent was not to gain the land by sheer force. Instead the invasions where explicitly geared at exploiting the de jure rules that required 'satisfactory levels of productivity.' The violence and conflict that often ensued as the land owner or the police tried to remove the occupants from the land served the purpose of attracting attention of the urban electorate through the media which avidly covered these events. Urban voters in Brazil sympathize with land reform due to the belief in social inclusion that pervades society, as well as the mistaken 
perception that land reform is merely redistributive and thus has no cost to them. ${ }^{7}$

The result of this state of affairs was that the government was compelled by the commotion raised by conflicts and violence to put in ever more effort and resources into land reform. This had the effect of strengthening the de jure rights but was not enough to make the de facto rights match the official rules. Thus the more effort the government made, the higher was the uncertainty of property rights and the greater the incentives for even more invasions and violence. This style of invasion-led land reform has resulted in a massive redistribution of land and resources to over one million needy families. It did not manage, however, to create a thriving substrate of productive family farms, as was the intention. The settlement projects that emerged from land reform at great expense in resources, environmental damage, violence and human suffering have rarely become independent and productive, with high levels of sales of plots and abandonment. Today Brazilian agriculture is still predominantly based on large mechanized farms and agribusinesses (MUELLER and MUELLER, 2012). By now this process has run most of its course and land reform has receded to the background, with few actual invasion of land, but rather other manifestations by the MST and other groups to expedite the release of credit and subsidies they are promised by the government. Thus, property rights to land in Brazil today may entail less uncertainty as regards conflicts and violence than they did in the past. But that is only after very huge rent dissipation has already taken place, ${ }^{8,9}$

\subsection{Missing tenancy markets}

Tenancy contracts, through which an owner rents out the use of the land to another agent in exchange for a fixed sum or a proportion of the production,

7. For a game theoretic treatment of the institutionally determined nature of rural conflicts in Brazil see (ALSTON et al. 1999; ALSTON et al., 2000). For an analysis of the voter sympathy as the key driver of land reform see (ALSTON et al., 2010)

8. The lessons from these experiences for the Forest Code will be drawn out in Section 5 .

9. For further evidence and analysis of rural conflicts in Brazil see (VERTOVA, 2006; ONDETTI, 2008; HIDALGO et al., 2010; BARROS et al., 2012; FETZER and MARDEN, 2105) have been prevalent throughout space and time. They can improve the allocation and use of resources by helping to allocate land to its highest valued uses and to deal with differential preferences for risk. In addition, tenancy can be a major instrument through which poor peasants with little experience can climb the agricultural ladder and achieve landownership. In a country such as Brazil, where there is an abundance of underused land together with large contingents of landless peasants, tenancy contracts would seem to be an ideal means to solve two problems at the same time. However, relative to most other countries Brazil seems to make remarkably low use of tenancy. Whereas in 1995 less than 5\% of the agricultural land was under tenancy contracts, in the US the comparable number was around $45 \%$ and in Belgium, France and Germany it was over 60\% (DE JANVRY et al., 2002). What is it that is impeding economic agents of engaging in tenancy contracts that could yield such obvious gains?

Once again we can turn to the Land Statute to search for the codified expression of the forces that have blocked greater use of tenancy and sharecropping. Two of the conditions for the social function to be met are that arrangements (i) "promote the welfare of the owners and the workers who toil in it, as well as their families", and (ii) "observe the laws governing fair working relationships between those who own the land those who cultivate it." These requirements reflect a deep suspicion, not wholly unfounded historically, that tenancy relations involve exploitation of peasants by powerful landowners. In a context where land reform and expropriations are a central part of the political debate, the sentiment expressed by this legislation had the effect of inducing many landowners to avoid tenancy relations, even when they were profitable from a purely economic point of view. Conning and Robinson (2007) present a model where the economic organization of agriculture and the political equilibrium determining the distribution of property are jointly determined. Their main result captures well what has happened in Brazil:

[...] despite possible economic benefits of tenancy, each landlord acting individually may choose to defensively limit the extent of tenancy in order to limit the possible consequence of future property challenges to their property (p. 421). 
Alston and Mueller (2010) use agricultural census data for all municipalities in Brazil by 1996 and show that a one-standard deviation increase in conflicts in the previous 10 years decreases the incidence of fixed rent contracts from $4 \%$ to less than $3 \%$ and of sharecropping from $2.5 \%$ to $1.3 \%$. In areas that have more conflicts land reform and the threat of expropriation is more salient, and thus the greater the risk to the owner of in entering tenancy contracts. ${ }^{10}$

\subsection{Deforestation}

Deforestation is the pathology due to insecure property rights that is most directly relevant for the Forest Code. Because forests are often remote and of difficult access, monitoring and enforcement of property rights is difficult, leading to great insecurity and uncertainty. There is a very large literature associating deforestation to dysfunctional property rights. Because of the Amazon, a large part of that literature is on Brazil. Some of these studies are: Mahar (1989); Binswanger (1991); Pfaff (1997); Alston et al., (1999); Alston et al., (2000); Margulis (2003); Acemoglu et al. (2005); Araujo Junior et al. (2008); AzevedosRamos (2008); Puppim De Oliveira (2008); Araujo et al. (2009); Pacheco (2009); Corbera et al. (2011); Barros et al. (2012); Assunção et al. (2013); Sant'anna and Young (2014); Assunção et al. (2015) among many more.

Although it is difficult to separate what is deforestation caused by insecure property rights from other types of deforestation, e.g. because it is profitable, the evidence from this literature makes it clear that property rights are a major issue. One channel through which property rights may induce deforestation is due to the requirement of maintaining satisfactory levels of productivity in the Land Statute and the Constitution. Cleared forest often serves as evidence of productive use and thus makes the land less susceptible to expropriation for the purposes of land reform. It is true that the same legislation requires the land to 'assure the conservation of natural resources', but this contradiction in the legislation just increases uncertainty. With the land reform agency promoting productive use and the environmental

10. Other papers analyzing the dearth of tenancy in Brazil are (BUAINAIN et al., 2008; ASSUNÇÃO and CHIAVARI, 2014). agency promoting conservation, it is often unclear for the landowner how to proceed, and the result has often been deforestation. In addition, clearing the forest makes invasions easier to detect and the property easier to protect. It is often noted that the forest is more valuable to society left standing than it is cut down, but given the difficulty of assigning the property rights to the different sticks in the bundle so that they can be negotiated, the result has often been to cut. Many schemes have sought to establish better incentives for more efficient use of the resources, such as the REDD+, and the central challenge there is precisely the issue of defining and ascertaining property rights.

The literature cited above has identified many other channels through which property rights influence deforestation and these will not be detailed here. The point to be stressed is that poorly defined property rights have been a central determinant of deforestation in the Amazon and elsewhere, and through very similar mechanisms they will be crucial for Forest Code policy.

\subsection{Distortion of investment decisions and crop choices}

When property rights are not secure many choices related to the use of the land may be distorted beyond what they would be under purely economic considerations. It is difficult to gauge the overall extent of rent dissipation due to these distortions, but several papers provide evidence for specific cases. Alston et al. (1996) find evidence of reduced land-specific investment as a response to weak titles in the Pará and Paraná frontiers. Vertova (2006) uses county-level data for Brazil to find evidence of sub-optimally large or premature investment as a means to strengthen insecure property rights. Bowser and Nelson (2012) find that land titles to low-income Afro-Brazilian communities (quilombos) lead to greater levels of income and welfare through their effect on production and investment, yet that only $5 \%$ of these communities had formal land titles.

Crop choice has also been shown to have been skewed away from purely economic and agricultural considerations. Alston et al., (2010) find that in those counties were there are more conflicts, and thus less secure property rights, the choice of which crops are planted is affected. Each crop has different implications 
for the risk of invasion and of expropriation. Natural pasture and unused land signal under-use of the land and hence increase the probability of the property being targeted for land reform. Many of the most valuable crops are temporary crops, such as soya (as opposed to permanent crops, such as coffee). Although a productive farm would not normally be subject to invasion or expropriation, a climate of insecurity in the region can nevertheless reduce investment. This study found that greater levels of conflicts had impacts at both the high and low intensity-of-use margins. A onestandard deviation increase in conflicts reduced the area in natural pasture by $17 \%$, of unused land by $3.7 \%$ and of temporary crops by $3.1 \%$, with compensating increases in planted pasture of $11.3 \%$ and permanent crops of $7.3 \%$. Because the exercise controls for other determinants of crop choice, the results suggest that insecure property rights are distorting crop choice decisions.

\subsection{Inequality in production}

Brazilian agriculture has always been highly concentrated. Yet, given the massive effort in land redistribution and in the official promotion of family farms in the past quarter century one would expect there to be at least a moderately well established and thriving stratum of small farms participating in the agricultural sector. But the data shows the shocking reality that less than $1 \%$ of the farms in Brazil generate more than half of the gross income, while the $66 \%$ less productive farms produce only $3.27 \%$ of the income (ALVES and ROCHA, 2010). This is such a highly skewed production profile that it suggests that much of the orientation of current Brazilian agricultural policy towards family farms may be by now a chimera.

Inequality is not a consequence of poorly defined property rights to land, but it is related in many ways. The belief in social inclusion, which has been argued to be the fundamental cause of the disjuncture between de jure and de facto property rights, is a direct aversion to inequality. The greater the level of inequality, the greater will be the reaction in terms of programs and policymaking to address this issue. This often leads to attempts to make the latent de jure rules and legislation come too life, which then increases the uncertainty of property rights leading to many of the pathologies noted above.

\subsection{Other impacts}

The consequences of insecure property rights to land discussed in this section are by no means a complete list of all the ways in which rents are dissipated and inefficiencies created due to the lack of better rules, norms, and institutions. Other examples are lobbying and rent-seeking expenses (ARAUJO JUNIOR et al., 2008; ONDETTI, 2008; ALSTON et al., 2010; ALBERTUS et al., 2015), and human suffering (WOLFORD, 2010). Many other examples are sure to exist, and this is still an active area of research.

\section{Lessons for the Forest Code}

What lessons can be learnt from the pathologies described above for the implementation of the Forest Code program? Some useful insights can be gained by a comparison of land reform and the Forest Code. Both are large scale policies that involve interfering directly with landowners' bundle of rights. While land reform removes from the owner the stick in the bundle relative to the right to leave the land unproductive, the Forest Code removes the right to cut down all of the vegetation. Although these requirements face in opposing directions they are nonetheless both constraints on the owner's liberty to choose what to do with the land. As such they are both subject to many of the same forces. In the previous section it was suggested that although land reform in Brazil did manage to redistribute vast areas of land, the program nonetheless failed to reach its objective of generating a large class of productive family farms. Let us see why this happened and consider the implications for the Forest Code.

The previous section described how the key determinant of the success of land reform in distributing so much land was the belief in social inclusion that pervades Brazilian society together with the symbolism of land reform in the eyes of the electorate as the way to compensate for past wrongs. A 2006 survey, for example, which asked respondents which reform the government should pursue first, had land reform at the top of the list when the question was open-ended. When a list of reforms was pre-specified, land reform was in the top 3 choices of over $45 \%$ of respondents (ABRAMO, 2006). Such preoccupation 
with land reform is remarkable in a country that is $80 \%$ urban and at a time when Brazilian agriculture was already one of the world's most productive.

Given that there was so much political support for the program, that so many resources were actually spent on the program, and that so much was actually done in terms of transferring land to landless peasants, why did the program fail in its main objectives? Alston et al. (2010) argue that the high level of popular support and scrutiny of the land reform program might have actually been a hindrance rather than a facilitator. An ongoing political debate became established on whether the government was doing enough in terms of land reform. This debate was constantly in the media and had important electoral consequences. Typically, it revolved around the federal government's claims to have settled a certain large number of families each year, and the denouncement by the opposition and by the MST that the government was not doing enough. Inevitably this debate ended up concentrating on a single metric: the number of families settled in land reform projects. The problem is that once a metric becomes the single measure of progress all sides have incentives to focus solely on that metric and to disregard other margins that are not observed but are crucial for the program's success, such as whether the peasants who were being given land were actually settling on it and making it productive or whether they were living off subsidies or selling the land. Under pressure to meet next year's ambitious targets the government had incentives to use cheaper frontier land (much of it in the Amazon) where the probability for settlers to thrive was much lower. The upshot was that the land reform program got deeply implemented along the one salient margin but was fatally under-implemented along several of the other crucial margins.

It is not clear whether the Forest Code is subject to the same sort of perverse incentives, but many of the same elements are present. Like land reform, the Forest Code is highly controversial and part of a public debate. There certainly is a large constituency that supports the program, though it is not clear if the issue is as deeply rooted in the electorate's collective consciousness as land reform has been. If this support turns out to be a lasting electoral issue, there will be incentives for the government to try to extoll its accomplishments in terms of the number of farms brought into compliance or the area of forest reserve protected. Similarly, critics will point out shortcomings in those same margins. Yet the ultimate objectives of the program are things that are much harder to measure and to prove, that is, things such as carbon sequestration, protection of biodiversity, preservation of the soil and water. The example of land reform warns that there is a risk that the political dynamics of the Forest Code could introduce distortions into which objectives are ultimately pursued.

Lessons for the Forest Code can also be gleaned from another property rights-related area, the success at reducing deforestation in Brazil since 2004. In the early 2000's almost nobody predicted that deforestation in the Amazon would start to subside at significant rates. The continual expansion of deforestation had always seemed impervious to all attempts to reverse the trends. Yet all the sudden the yearly statistics started turning up encouraging numbers. How was this achieved? Might similar strategies be helpful for the Forest Code, which is clearly a related policy? The jury is still out on exactly what were the forces that led to the happy outcomes in deforestation (and whether they are sustainable), and no attempt will be made here to settle this issue. Yet one interpretation will be highlighted, as it seems to point to some characteristics of the policies used that might be similarly effective in the case of the Forest Code. A typical reaction when confronted with the task of making a policy work is to suggest that the policymaker should simply put more political will, effort and resources to really enforce the rules. This is a very top-down approach and, as seen in the case of land reform, doesn't always manage to deal with all the difficulties that can emerge. Economist (2013) provides an interpretation of the fall in deforestation in the Amazon that tells a very different type of story. This interpretation focuses on the simultaneous confluence of factors acting on deforestation, many of them at the local level. Although there is an important role played by the federal environmental agency, many other players are present in this story, mayors and governors facing competitive electoral pressure for conservation, national and international NGOs, a strong environmental sentiment and movements, independent public attorneys, a free and active press, companies constrained by corporate social responsibility not to purchase from farmers who deforest, among others. It would probably be a useful strategy for the Forest Code program to elicit a similar 
local and dispersed set of forces rather than relying solely on centralized implementation.

\section{Conclusions}

This paper has cast the major problem faced by Forest Code legislation as the uncertainty regarding property rights to land. In particular, the problem lies in the stick in the bundle of rights that pertains to the right to cut the area known as the legal reserve of the property. De jure legislation places that stick in the hands of society, which has the right to the benefits that emanate from the standing vegetation (carbon sequestration, biodiversity etc.) Yet de facto property rights have been such that landowners have truly held that stick of the bundle, and many of them chose to cut down the corresponding area. The renewed effort to truly implement the Forest Code strengthens the de jure rights, but not enough to make de facto rights the same as what is in the legislation. The uncertainty that ensues can have perverse incentives leading to conflict, violence, deforestation, investment and crop choice distortions, among others. This suggests that a key objective of the new program should be to reduce that uncertainty by credibly signaling which rules will prevail.

If property rights were perfectly defined and transaction costs were negligible, then it really would not matter for the efficient use of the land who had the right to the legal reserve, the landowner or society, as it would always be possible and worthwhile to negotiate to reach the optimal allocation. This is an application of the most influential insight in the property rights literature, known as the Coase Theorem (COASE, 1960). If we accept that the efficient thing to do is to have a standing legal reserve in each property, then under the condition of the Coase Theorem (clear property rights and no transaction costs) either society has the right to the legal reserve and it is kept standing by the owner, or the owner has the right to the reserve and society compensates him/her for not cutting it down. Whoever has the property right has an impact on who bears the cost, but does not affect whether the legal reserve will be kept standing or not.

The point of the Coase Theorem is not that this desirable outcome will automatically be realized. On the contrary, the expectation is that property rights are generally ill-defined and insecure, and transaction costs typically make negotiations prohibitive. Under such real world circumstances the use of the resource that emerges will consequently not be the same efficient outcome of the idealized conditions. Who has the actual property right to the resource turns out to be truly consequential, not only for the determination of who incurs the costs, but also whether the legal reserve is kept standing. Brazilian legislation has decided that the property right to the legal reserve belongs to society. Thus, society has a right to expect landowners to leave a predetermined portion of their land in natural vegetation. This has been a disputed and controversial decision, but if we accept that this is what will prevail, then how should the Forest Code program be pursued so as to ensure the best use of the resource. The Coase Theorem suggests two important margins through which the implementation of the program could work to ensure its success: clear property rights and low transaction costs.

Clear property rights cannot simply be decreed; they have to be achieved through consistency of implementation of the rules. As the government consistently demonstrates that it will follow and uphold the legislation, not overstepping its bounds and not failing to punish those who deviate, in an impersonal way and without exceptions, the credibility of the program will emerge making de jure and de facto rules converge. Reducing transaction costs involves making it easier for all parties to reach negotiated alternatives that still meet the legislation but do so in a less costly way. The legislation and the implementation of the program have already started pursuing several means of facilitating these transactions, for example by allowing for owners of highly productive land to purchase a compensating legal reserve in less productive land. Such schemes not only make economic sense, but should also help to increase compliance. Although they have to be carefully managed, they can make the difference between the success and failure of Brazil's grand policy experiment with property rights.

\section{References}

ABRAMO, F. P. Imagens dos partidos e cultura politica. 2006. Disponível em: < http://www2.fpa.org.br/portal/ modules/news/index.php? storytopic $=1113>$. Acesso em: 02 fev. 2010. 
ACEMOGLU, D., JOHNSON, S. and ROBINSON, J. Institutions as a fundamental cause of long-run growth. In: AGHION, P. and DURLAF, S. N. (Eds.). Handbook of economic growth. Vol. 1. Elsevier, 2005, p. 385-472.

. and ROBINSON, J. A. Why nations fail: the origins of power, prosperity, and poverty. New York: Crown Publishers, 2012.

ALBERTUS, M., BRAMBOR, T. and CENEVIVA, R. Land inequality and rural unrest: theory and evidence from Brazil. 2015.

ALSTON, L. J., LIBECAP, G. D. and SCHNEIDER, R. The determinants and impacts of property rights: land titles on the brazilian frontier. Journal of Law, Economics and Organization, v. 12, n. 1, p. 25-61, 1996.

., LIBECAP, G. D. and MUELLER, B. A model of rural conflict: violence and land reform policy in Brazil. Environment and Development Economics, v. 4, n. 2, p. 135-160, 1999.

LIBECAP, G. D. and MUELLER, B. Land Reform Policies, the sources of violent conflict, and implications for deforestation in the Brazilian Amazon. Journal of Environmental Economics and Management, v. 39, n. 2, p. $162-188,2000$.

. and MUELLER, B. Legal reserve requirements in brazilian forests: path dependent evolution of de facto legislation. Economia, v. 7, n. 4, p. 25-53, 2007.

., LIBECAP, G. D. and MUELLER, B. Interest groups, information manipulation in the media, and public policy: the case of the landless peasants movement in Brazil. NBER Working Paper, v. 15865, 2010.

and MUELLER, B. Property rights, land conflict and tenancy in Brazil. NBER Working Paper, v. 15771, 2010.

.,HARRIS, E. andMUELLER, B. The development of property rights on frontiers: endowments, norms, and politics. The Journal of Economic History, v. 72, n. 3, p. 741-770, 2012.

Towards a more evolutionary theory of property rights. Iowa Law Review, v. 100, p. 2255-2274, 2015.

. et al. Brazil in transition: beliefs, leadership and institutional change. Princeton: Princeton University Press, 2016.

ALVES, E. and ROCHA, D. P. Ganhar tempo é possível? In: GASQUES, J. G. and NAVARRO, Z. (Eds.). A agricultura brasileira. Desempenho, desafios, perspectivas. Brasilia: IPEA, 2010. p. 275-290.
ARAUJO, C. et al. Property rights and deforestation in the Brazilian Amazon. Ecological Economics, v. 68, n. 8-9, p. 2461-2468, 2009.

ARAUJO JUNIOR, A. F. D., SHIKIDA, C. and ALVARENGA, P. S. Economia política da disputa por terras em Minas Gerais. Revista de Economia e Sociologia Rural, v. 46, p. 803-830, 2008.

ASSUNÇÃO, J. et al. Does credit affect deforestation? Evidence from a rural credit policy in the brazilian Amazon, 2013.

. and CHIAVARI, J. Land rental markets in Brazil: a missed opportunity, 2014.

., GANDOUR, C. and ROCHA, R. Deforestation slowdown in the brazilian Amazon: prices or policies? Environment and Development Economics, v. 20, n. 6, p. 697-722, 2015.

AZEVEDOS-RAMOS, C. Sustainable development and challenging deforestation in the brazilian Amazon: the good, the bad and the ugly. Unasylva, v. 59, p. 12-16, 2008.

BARROS, C. P., ARAUJO JUNIOR, A. F. and FARIA, J. R. Brazilian land tenure and conflicts: the landless peasants movement. Cato Journal, v. 33, n. 1, p. 47-75, 2012.

BARZEL, Y. Economic analysis of property rights. Cambridge University Press, 1997.

BINSWANGER, H. P. Brazilian policies that encourage deforestation in the Amazon. World Development, v. 19, n. 7, p. 821-829, 1991.

BOWSER, W. and NELSON, C. H. Land institutions, investments, and income diversification: pathways to economic development for Brazil's quilombo communities. International Food Policy Research Institute (IFPRI). Washington. 2012

BUAINAIN, A. M. et al. Land rental markets and land access in Brazil. Land Tenure Center. Madison, 2008.

CHIVARI, J. and LOPES, C. L. Brazil's New Forest Code: how to navigate the complexity. Climate Policy Initiative, 2015.

COASE, R. H. The problem of social cost. The Journal of Law and Economics, v. III, p. 1-44, 1960.

CONNING, J. H. and ROBINSON, J. A. Property rights and the political organization of agriculture. Journal of Development Economics, v. 82, n. 2, p. 416-447, 3// 2007.

CORBERA, E. et al. Rights to land, forests and carbon in REDD+: Insights from Mexico, Brazil and Costa Rica," Forests. Forests, v. 2, p. 301-342, 2011. 
DE JANVRY, A., MACOURS, K. and SADOULET, E. Access to land in the rural development agenda. InterAmerican Development Bank. Washington. 2002

DEMSETZ, H. Toward a theory of property rights. American Economic Review (Papers and Proceedings), v. 57, n. 2, p. 347-359, 1967.

ECONOMIST, T. Trees of knowledge. The Economist: The Economist Newspaper Ltd. 2013.

EGGERTSSON, T. Economic behavior and institutions. Cambridge University Press, 1990.

FENNELL, L. Ostrom's law: property rights in the commons. International Journal of the Commons, v. 5, n. 1, p. 9-27, 2011.

FETZER, T. and MARDEN, S. Take what you can: property rights, contestability and conflict. University of Warwick. 2105

FIELD, E. Property rights and investment in urban slums. Journal of the European Economic Association, v. 3, n. 2-3, p. 279-290, 2005.

HARDIN, G. The tragedy of the commons. Science, v. 162, n. 3859, p. 1243-1248, 1968.

HIDALGO, F. D. et al. Economic determinants of land invasions. Review of Economics and Statistics, v. 92, n. 3, p. 505-523, 2010.

HIRAKURI, S. R. Can law save the forest?: lessons from Finland and Brazil. Bogor, Indonesia: CIFOR, 2003.

KLEIN, D. and ROBINSON, J. Symposium: Property: A Bundle of Rights? Econ Journal Watch, v. 8, n. 3, sept. 2011.

MAHAR, D. J. Government policies and deforestation in Brazil's Amazon region. Washington. 1989

MARGULIS, S. Causas do desmatamento da Amazônia brasileira. Washington. 2003.

MUELLER, B. The economic theory of regulation: the Case of Agrarian Reform Legislation in Brazil. Revista Brasileira de Economia, v. 52, n. 1, p. 83-110, 1998.

. The economics of the brazilian model of agricultural development. BWPI, The University of Manchester, 2014.

. and MUELLER, C. The impact of the 20072008 food price crisis in a major commodity exporter: food prices, inflation, and inclusion in Brazil. World Institute for Development Economic Research (UNUWIDER) 2012.
NORTH, D. C., WALLIS, J. J. and WEINGAST, B. R. Violence and social orders: a conceptual framework for interpreting recorded human history. Cambridge [u.a.]: Cambridge Univ. Press, 2009

ONDETTI, G. Land, protest, and politics: the landless movement and the struggle for agrarian reform in Brazil. University Park, PA: Pennsylvania State University Press, 2008.

OSTROM, E. Governing the commons: the evolution of institutions for collective action. Cambridge University Press, 1990.

. Design principles of robust property rights institutions: what have we learned. In: INGRAM, G. K. and HONG, Y. (Eds.). Property rights and land policies. Proceedings of the 2008 Land Policy Conference, 2009, Lincoln Land Institute.

PACHECO, P. Agrarian reform in the brazilian Amazon: its implications for land distribution and deforestation. World Development, v. 37, n. 8, p. 1337-1347, 2009.

PFAFF, A. What drives deforestation in the brazilian Amazon? Evidence from satellite and socioeconomic data. Washington DC. 1997

PUPPIM DE OLIVEIRA, J. A. Property rights, land conflicts and deforestation in the Eastern Amazon. Forest Policy and Economics, v. 10, n. 5, p. 303-315, 2008.

SANT'ANNA, A. A. and YOUNG, C. E. F. Property rights, deforestation and violence: problems for the development of the Amazon. Policy in Focus, v. 29, p. 28-30, 2014.

SOARES-FILHO, B. et al. Cracking Brazil's Forest Code. Science, v. 344, n. 6182, p. 363-364, 2014.

SOKOLOFF, K. and ENGERMAN, S. History lessons: institutions, factors endowments, and paths of development in the new world. The Journal of Economic Perspectives, v. 14, n. 3, p. 217-232, 2000.

SOTO, H. The mystery of capital: why capitalism triumphs in the West and fails everywhere else. Basic Books, 2003. ISBN 0465016154.

VERTOVA, P. Property rights on unused asset and investment incentives: evidence from Brazil. Tilburg University, Center for Economic Research, Discussion Paper, v. 48, 2006.

WOLFORD, W. This land is ours now: social mobilization and the meaning of land in Brazil. Duke University Press, 2010.

Todo o conteúdo deste periódico, exceto onde estiver identificado, está licenciado sob uma Licença Creative Commons (cc by 4.0) 